$\square$ 원 $\quad$ 저 $\square$

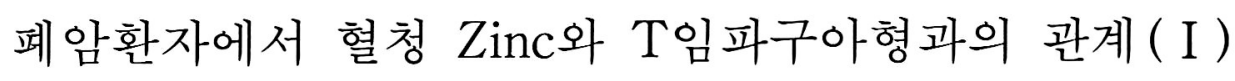

\author{
충남대학교 의과대학 내과학교실 \\ 김선영・남재만·이경주 · 손경선
}

$=$ Abstract $=$

\title{
Association between Serum Zinc Levels and T-Cell Subsets in Patients with Lung Cancer
}

Sun Young Kim, M.D., Jae Man Nam, M.D., Kyoung Joo Rhee, M.D. and Kyung Sun Son, M.D.

Department of Internal Medicine, College of Medicine, Chung Nam National University

To ascertain the changes in serum \& urinary zinc levels in patients with bronchogenic carcinoma, we measured serum zinc level and 24 hour urinary zinc exceretion in 25 normal controls and 38 lung cancer patients.

1) Mean serum zinc level was significantly lower in patients with lung cancer $(64.1 \pm 21.9 \mathrm{ug} / \mathrm{dl})$ than in normal controls $(75.1 \pm 10.6 \mathrm{ug} / \mathrm{dl})(\mathrm{p}<0.05)$.

2) 24 hour urinary zinc excretion was higher in patients with lung cancer $(1066 \pm 592 \mathrm{ug} / 24 \mathrm{hr})$ than in normal controls $(604 \pm 262 \mathrm{ug} / 24 \mathrm{hr})(\mathrm{p}<0.02)$.

3) There were no statistically significant differences in serum zinc levels \& 24 hour urinary zinc excretion between patients with limited disease and patients with extensive disease, also patients with small cell carcinoma \& patients with non-small cell carcinoma.

4) Percent of $\mathrm{OKT}_{4}{ }^{+}$cells was significantly lower in patients with lower serum zinc levels $(33 \pm 9$. $79 \%)$ than patients with higher serum zinc levels $(46.57 \pm 7.93 \%)(\mathrm{p}<0.02)$.

Patients with lung cancer often have lower serum zinc concentration and zinc deficiency may be an important cause of abnormal T-cell function. Zinc supplementation may be useful to improve lymphocyte function in zine deficient patients. Whether zinc supplementation would alter the course of the disease or the patients is unknown.

\section{서 론}

$\mathrm{Zn}$ 는 세포기능과 성장에 중요한 필수 미량원소로서 혈 청 $\mathrm{Zn}$ 치는 나이가 증가함에 따라 감소하며 남자보다 여 자에서 낮다고 보고되어 있달. 혈청 $\mathrm{Zn}$ 치는 폐암, 대 장암, 당뇨병, 간경화, 간염, 폐결핵, 심근경색증, 신

*본 논문은 1987 년 제 65 차 대한결핵학회 추계학술대회에 서 발표 되었음.
부전증, 급성조직손상, 임신등에서 감소하며, 스테로이 드 복용시도 감소한다고 한다2).

$\mathrm{Zn}$ 결핍은 포면상피 위장관, 내막세포, 임파구등 빠르 게 성장하는 세포에서 흔히 관찰된다. 그러므로 $\mathrm{Zn}$ 결핍 시 탈모증 선단피부염, 발육부전, 임파구기능장애등이 초래될 수 있다1).

Robert등 ${ }^{3)}$ 은 $\mathrm{Zn}$ 결핍시 임파구감소증, $\mathrm{T}$ 억제세포의 증가, $\mathrm{T}$ 조력세포의 감소, 자연살해세포 활동성의 감소 등이 발생한다 하였다. Brian등4)은 폐암환자에서 혈청 
$\mathrm{Zn}$ 치가 감소하며 치료전 혈청 $\mathrm{Zn}$ 치가 높은 환자에서 생 존율이 높다고 하였고, Morgan등5)도 폐암환자에서 혈 청 $\mathrm{Zn}$ 치가 감소함을 보고하였다.

저자들은 폐암환자에서 혈청 및 24시간 뇨중 $\mathrm{Zn}$ 치 및 말초혈액 $\mathrm{T}$ 임파구아형분석을 시행하여 $\mathrm{Zn}$ 결핍과 면역 기능변화와의 관계를 관찰하고자 하였다.

\section{대상 및 방법}

\section{1. 대 상}

1987년 4월부터 1987년 10월까지 충남대학교병원 내 과에 입원하여 조직학적으로 진단된 38 명의 폐암환자를 대상으로 혈중 및 뇨중 $\mathrm{Zn}$ 치를 측정하였고, 그중 14 명 에서 T임파구아형분석을 시행하였다. 남자가 29 명, 여 자가 9 명이었으며 이들의 평균나이는 58.3세였다 (Table 1). 조직학적 유형별로는 편평상피암 25예, 선암 4예, 소세포암 9예였으며, 진행정도에 따라서는 제한암이 5 예, 진행암이 33 예였다(Table 2). $\mathrm{Zn}$ 치의 정상대조군 은 건강한 정상성인 25 명 (남자 13 명, 여자 12 명)으로 이 들의 평균연령은 38.7 세였다 (Table 1). T임파구아형분 석의 정상대조군은 건강한 정상성인 28 명으로 이들의 평 균연령은 35 세였다.

환자군과 대조군에서 $\mathrm{Zn}$ 의 제한식 또는 $\mathrm{Zn}$ 가 포함된 악제투여는 하지않았으며, 혈액검사, 간기능검사, 신기

Table 1. Characteristics of Subjects

\begin{tabular}{|c|c|c|}
\hline & Control & Lung cancer \\
\hline \multicolumn{3}{|c|}{ Number of subjects } \\
\hline Male & 13 & 29 \\
\hline Female & 12 & 9 \\
\hline Age & 38.7 & 58.3 \\
\hline
\end{tabular}

Table 2. Cell Type and Stage of Patients

\begin{tabular}{llr}
\hline \hline \multirow{2}{*}{ Pathology } & $\begin{array}{c}\text { Number of } \\
\text { patients (\%) }\end{array}$ \\
\cline { 2 - 3 } & Squamous cell carcinoma & $25(66)$ \\
& Adenocarcinoma & $4(10)$ \\
& Small cell carcinoma & $9(24)$ \\
& Limited (stage I \& II) & $5(13)$ \\
& Extensive (stage III) & $33(87)$ \\
\hline
\end{tabular}

능검사등에 이상이 없었다.

\section{2. 방 법}

1) $\mathrm{Zn}$ 검사 : 혈청 $\mathrm{Zn}$ 검사를 위한 채혈은 플라스틱 주 사기를 사용하여 공복시에 시행하였다.

이때 용혈이 일어나지 않도록 주의하였고 혈청분리후 $3 \sim 4^{\circ} \mathrm{C}$ 의 냉장실에 보관하였다가 aa/ae Spectrophotometer 551 을 사용하여 분광측정하였다.

24시간 뇨는 산처리된 polyethylene bottle에 채취하 여 냉암소에 보관하였다가 동일한 방법으로 측정하였다.

모든 폐암환자에서 staging을 시행하여 암의 진행정 도, 조직학적 유형에 따른 $\mathrm{Zn}$ 치의 변화를 비교관찰하였 다.

2) 말초혈액 T임파구아형분석 : Ortho사의 OKT4, $\mathrm{OKT} 8$ 단세포항체를 사용하여 저자들6)이 전에 보고한 것 과 동일한 방법으로 말초혈액 $\mathrm{T}$ 임파구아형분석을 시행 하여 혈청 $\mathrm{Zn}$ 치와의 관계를 관찰하였다.

\section{결 과}

\section{1. 폐암환자에서 혈청 및 24 시간 뇨증 $\mathrm{Zn}$ 치}

혈청 $\mathrm{Zn}$ 치는 정상대조군에서 $75.1 \pm 10.6 \mu \mathrm{g} / \mathrm{dl}$, 폐암 환자군에서 $64.1 \pm 21.9 \mu \mathrm{g} / \mathrm{dl}$ 로, 폐암환자군에서 유의 하게 감소하였다 $(\mathrm{p}<0.05)$ (Table 3$)$.

24시간 뇨중 $\mathrm{Zn}$ 배설량은 정상대조군에서 $604 \pm 262$

Table 3. Serum \& Urine Zinc Levels in Lung Cancer

\begin{tabular}{lcc}
\hline \hline & $\begin{array}{c}\text { Normal } \\
\text { c controls }\end{array}$ & Lung cancer \\
\hline Serum zinc (ug/dl) & $75.1 \pm 10.6$ & $64.1 \pm 21.9 *$ \\
Urine zinc $(\mathrm{ug} / 24 \mathrm{hr})$ & $604 \pm 262$ & $1066 \pm 592 * *$ \\
\hline$*$ P value $<0.05, * * P$ value $<0.02$ &
\end{tabular}

Table 4. Serum \& Urine Zinc According to Stage

\begin{tabular}{cccc}
\hline \hline & $\begin{array}{l}\text { Limited } \\
\text { disease }\end{array}$ & $\begin{array}{l}\text { Extensive } \\
\text { disease }\end{array}$ & P value \\
\hline $\begin{array}{c}\text { Serum zinc } \\
\text { (ug/dl) } \\
\text { Urine zinc } \\
\text { (ug/24hr) }\end{array}$ & $70 \pm 8.68$ & $63.5 \pm 22$ & NS \\
\hline
\end{tabular}

NS : Not significant 
$\mu \mathrm{g} / 24 \mathrm{hr}$, 폐암환자군에서 $1066 \pm 592 \mu \mathrm{g} / 24 \mathrm{hr}$ 으로 폐 암환자군에서 유의하게 증가하였다 $(\mathrm{p}<0.02)$ (Table 3).

폐암의 진행정도에 따른 혈청 $\mathrm{Zn}$ 치는 제한암이 $70 \pm$ $8.68 \mu \mathrm{g} / \mathrm{dl}$, 진행암이 $63.5 \pm 22 \mu \mathrm{g} / \mathrm{dl}$ 로 진행암에서 감 소하는 경향이 있었으나 통계적인 유의성은 없었다 (Table 4). 24시간 뇨중 $\mathrm{Zn}$ 치는 제한암 $1067 \pm 515 \mu \mathrm{g} /$ $24 \mathrm{hr}$, 진행암 $1077 \pm 611 \mu \mathrm{g} / 24 \mathrm{hr}$ 로 유의한 차이가 없었 다 (Table 4).

진행암중 소세포암과 비소세포암의 헐청 $\mathrm{Zn}$ 치는 각각 $59.6 \pm 19.6 \mu \mathrm{g} / \mathrm{dl}, 64.6 \pm 23.6 \mu \mathrm{g} / \mathrm{dl}$ 로 유의한 차이가 없었으며, 24 시간 뇨중 $\mathrm{Zn}$ 치는 각각 $987.3 \pm 60.75 \mu \mathrm{g} /$ $24 \mathrm{hr}, \quad 1089 \pm 617 \mu \mathrm{g} / 24 \mathrm{hr}$ 로 유의한 차이가 없었다 (Table 5).

\section{2. 혈청 $\mathrm{Zn}$ 치에 따른 $\mathrm{T}$ 임파구아형분석}

혈청 $\mathrm{Zn}$ 치가 $70 \mu \mathrm{g} / \mathrm{dl}$ 이상인 환자들에서 조력임파구 를 나타내는 OKT4양성세포백분율이 $46.57 \pm 7.93 \%$, 억제임파구를 나타내는 OKT8 양성세포백분율이 $24.57 \pm 6.72 \%, \mathrm{OKT}_{4}^{+} / \mathrm{OKT}^{+}$비는 $2.0 \pm 0.59$ 였다. 혈청 $\mathrm{Zn}$ 치가 $70 \mu \mathrm{g} / \mathrm{dl}$ 이하인 환자에서 $\mathrm{OKT} 4$ 양성세포

Table 5. Serum \& Urine Zinc According to Cell Type in Extensive Disease

\begin{tabular}{lccl}
\hline & $\begin{array}{l}\text { Small cell } \\
\text { carcinoma }\end{array}$ & $\begin{array}{l}\text { Nonsmall } \\
\text { cell carci- } \\
\text { noma }\end{array}$ & P value \\
\hline $\begin{array}{c}\text { Serum zinc } \\
\text { (ug/dl) }\end{array}$ & $59.6 \pm 19.6$ & $64.6 \pm 23.6$ & NS \\
$\begin{array}{c}\text { Urine zinc } \\
\text { (ug/24hr) }\end{array}$ & $987.3 \pm 607.5$ & $1089.9 \pm 617.1$ & NS \\
\hline
\end{tabular}

NS : Not significant
백분율은 $33.0 \pm 9.79 \%, \quad \mathrm{OKT} 8$ 양성세포백분율은 $26.57 \pm 8.94 \%, \mathrm{OKT}^{+} / \mathrm{OKT}^{+}$비는 $1.39 \pm 0.54$ 로 혈 청 $\mathrm{Zn}$ 치가 낮은 환자들에서 $\mathrm{OKT} 4$ 양성세포백분율이 유 의하게 감소하였다 $(\mathrm{p}<0.02)$. OKT8 양성세포백분율과 $\mathrm{OKT} 4^{+} / \mathrm{OKT} 8^{+}$비는 양군간에 유의한 차이가 없었다. 또한 혈청 $\mathrm{Zn}$ 치가 높은 환자들의 $\mathrm{T}$ 임파구아형분석은 정 상대조군과 유의한 차이가 없었다 (Table 6).

\section{고 안}

$\mathrm{Zn}$ 는 1940년 Keilin등기이 처음 발견한 필수 미량원소 로 약 70여종의 Zn metalloenzyme이 알려져 있다. Leon등8)은 $\mathrm{Zn}$ 가 polynucleotide합성과 세포증식에 관 여하여 $\mathrm{Zn}$ 결핍시 Thymidine의 DNA에의 융합이 감소 되며, DNA polymerase와 Thymidine kinase, RNA polymerase의 억제로 RNA와 DNA의 합성감소를 보고 하였다. 또한 원형질막의 통합성 소실로 세포구조의 변 화를 초래한다고 하였다. John ${ }^{910)}$ 등은 $\mathrm{Zn}$ 가 탄수화물 및 지방의 대사과정에 관여하며 단백질합성과 교원질합성에 중요한 역할을 한다고 하였다. James등1)은 영양결핍으 로 인한 왜소발육증환자에서 $\mathrm{Zn}$ 투여후 성기능의 정상화 와 신장의 성장을 관찰하였다 한다.

혈청 $\mathrm{Zn}$ 는 폐암 및 대장암환자에서 감소한다는 보고 가 있고, 혈청 $\mathrm{Zn}$ 치 감소시 세포면역기능의 감소에 대 한 많은 연구가 있다 ${ }^{12 \sim 14,16)}$. Gabriel등 ${ }^{14)}$ 은 $\mathrm{Zn}$ 결핍된 쥐 에서 체중감소, 임파조직 중량감소, T살해세포활동력의 감소, 자연살해세포활동력의 감소를 관찰하였고, $\mathrm{ADCC}$ (Antibody-dependent cell-mediated cytotoxicity) 는 정상이었음을 관찰하였다 한다. John등리은 완전 비경 구적 고영양요법중 발생한 $\mathrm{Zn}$ 결핍에서 phytohemagg. lutinin에 대한 순환 T임파구의 반응이 크게 감소하였고,

Table 6. T-Cell Subsets According to Serum Zinc Levels

\begin{tabular}{|c|c|c|c|}
\hline & \multirow[b]{2}{*}{$\begin{array}{l}\text { Normal controls } \\
\qquad(N=28)\end{array}$} & \multicolumn{2}{|c|}{ Lung cancer patients } \\
\hline & & $\underset{(N=7)}{\operatorname{Serum}} \operatorname{zinc} \geqslant 70 \mathrm{ug} / \mathrm{dl}$ & $\underset{(N=7)}{\operatorname{Serum} z i n c}<70 \mathrm{ug} / \mathrm{dl}$ \\
\hline $\mathrm{OKT}_{4}^{+}$ & $43.8 \pm 8.9 \%$ & $46.57 \pm 7.93 \%$ & $33.0 \pm 9.79 \% *$ \\
\hline OKT ${ }^{+}$ & $29.7 \pm 7.7 \%$ & $24.57 \pm 6.72 \%$ & $26.57 \pm 8.94 \%$ \\
\hline $\mathrm{OKT} 4^{+} / \mathrm{OKT}^{+}$ & $1.5 \pm 1.5$ & $2.00 \pm 0.69$ & $1.39 \pm 0.54$ \\
\hline
\end{tabular}

* $P$ value $<0.02$ in patients with lower vs higher zinc levels.

* P value $<0.02$ in patients with lower zinc levels vs normal controls. 
20 일 동안의 $\mathrm{Zn}$ 공급후 임파구의 반응이 정상화되었음을 보고하였다. Robert등 ${ }^{15)}$ 은 $\mathrm{Zn}$ 결핍환자에서 dinitrochlorobenzene에 대한 지연성 피부과민반응검사와 시험관 내 임파구 transformation이 감소하여 3 주간의 $\mathrm{Zn}$ 공급 후 이러한 반응이 정상화되면서 안면지루 및 욕창이 빠 르게 회복됨을 관찰하였다 한다. Jean등 ${ }^{13)}$ 은 70세이상 의 노인들에서 1 개월 동안 매일 $440 \mathrm{mg}$ 의 $\mathrm{Zn}$ 를 공급한 결 과, 순환 $\mathrm{T}$ 임파구수, 지연형피부과민반응, tetanus 백 신에 대한 IgG 항체반응의 증가를 보여 노인들에서 $\mathrm{Zn}$ 공급이 면역기능의 향상에 도움이 된다고 보고하였다. Robert등 ${ }^{3)}$ 은 $\mathrm{Zn}$ 결핍이 임파구와 단핵구의 기능을 변화 시켜, 임파구감소증, T세포 mitogen반응의 감소, 순환 $\mathrm{T}$ 억제세포의 증가, 순환 $\mathrm{T}$ 조력세포의 감소, 자연살해 세포 활동력의 감소, 단핵구 세포독작용의 증가를 초래 한다 하였다. 반면 이들에서 $\mathrm{Zn}$ 보충후 말초혈액 임파구 수의 증가, OKT4/OK8비의 정상화, mitogen에 대한 $\mathrm{T}$ 세포반응의 정상화, 자연살해세포기능의 향상, 단핵구 세포독작용의 정상화를 보고하며, 자연살해세포와 단핵 구세포독작용이 종양면역에 중요하므로 $\mathrm{Zn}$ 대사의 이상 이 종양면역감시체계에 중요한 변화를 초래할 것이라 하 였다.

Allen등은 폐암환자에서 소변으로의 $\mathrm{Zn}$ 배설과 임파 구기능장애와의 관계를 고찰한 결과, 폐암환자에서 혈청 $\mathrm{Zn}$ 치의 감소, 신장의 $\mathrm{Zn}$ 배설증가, $\mathrm{T}$ 세포 phytohemagglutinin반응이 감소됨을 관찰하였고, $\mathrm{Zn}$ 공급후 이 반응 이 정상화됨을 보고하였다. 그러나 이들은 말초혈액 자 연살해세포활동력이 혈청 $\mathrm{Zn}$ 치와 상관이 없었고 $\mathrm{Zn}$ 공급 후에도 변화가 없었으므로, 폐암환자에서 $\mathrm{Zn}$ 공급이 환 자의 종양면역능을 증강시킬 수 없어도 $\mathrm{T}$ 세포매개성면 역을 증강시킬 수 있어 세균감염에 대한 저항 및 $\mathrm{T}$ 세포 매개성 세포독작용등을 증폭시킬 수 있다 하였다.

본 연구에서도 이전의 보고와 거의 동일한 결과를 보 여, 폐암환자에서 혈청 $\mathrm{Zn}$ 의 유의한 감소와 소변 $\mathrm{Zn}$ 배 설의 유의한 증가가 있음을 알 수 있었고, 폐암환자에서 $\mathrm{Zn}$ 대사의 이상이 있음을 확인할 수 있었다. 그러나 혈 청 $\mathrm{Zn}$ 는 나이가 증가함에 따라 감소하므로, 본연구에서 대조군에 비해서 환자군의 평균연령이 많았던 점이 또한 폐암환자의 혈청 $\mathrm{Zn}$ 감소의 한 요인이 되었으리라 사료 된다. 폐암환자에서 혈청 $\mathrm{Zn}$ 치 감소의 원인에 대해서 ${ }^{17)}$ 서등ㄱ)은 (1) 영양부족 및 간조직의 $\mathrm{Zn}$ 흡수증가 (2) 암세 포의 $\mathrm{Zn}$ 대사요구량증가, (3) 혈청단백감소로 인한 신장
의 $\mathrm{Zn}$ 배설증가등에 대해서 이야기했으나 아직 그 확실 한 기전은 밝혀져 있지 않다.

또한 본 연구에서 혈청 $\mathrm{Zn}$ 치가 $70 \mu \mathrm{g} / \mathrm{dl}$ 이하인 환자 에서 시행한 말초혈액 $\mathrm{T}$ 임파구아형분석 결과 조력 $\mathrm{T}$ 세 포 (OKT4 양성세포)의 유의한 감소를 보인 반면, 혈청 $\mathrm{Zn}$ 치가 $70 \mu \mathrm{g} / \mathrm{dl}$ 이상인 환자에서는 정상대조군과 통계 적으로 유의한 차이가 없었다. 이러한 결과는 Robert 등디의 연구와 일치되며, 폐암환자에서 혈청 $\mathrm{Zn}$ 대사의 장애로 말초혈액 조력임파구가 억제됨을 알 수 있었다.

아직 혈청 $\mathrm{Zn}$ 의 감소가 자연살해세포 및 단핵구에 미 치는 영향에 대해서는 논란이 많지만, 폐암환자에서 $\mathrm{Zn}$ 대사의 변화로 면역기능이 억제되어 폐암의 분화 및 전 이에 영향을 주며, 여러 감염증에 대한 저향력을 약화시 킬 수도 있을 것으로 사료된다4). $\mathrm{Zn}$ 결핍된 폐암환자에 서 수술적 요법, 항암제투여, 방사선치료와 더불어 $\mathrm{Zn}$ 공급으로 변화된 환자의 면역기능의 정상화를 기대해볼 수 있을 것으로 사료되나 차후 이에 대한 좀더 많은 연 구가 있어야 할 것이다.

\section{결 론}

저자들은 충남대학교병원 내과에 입원하여 조직학적으 로 진단된 38 명의 폐암환자를 대상으로 혈청 및 24 시간 뇨중 $\mathrm{Zn}$ 배설량 및 말초혈액 $\mathrm{T}$ 임파구아형분석을 시행하 여 다음과 같은 결과를 얻었다.

1) 폐암환자군에서 혈청 $\mathrm{Zn}$ 치는 $64.1 \pm 21.9 \mu \mathrm{g} / \mathrm{dl}$ 로 정 상대조군의 $75.1 \pm 10.6 \mu \mathrm{g} / \mathrm{dl}$ 에 비해 유의하게 감소 하였으며 $(\mathrm{p}<0.05), 24$ 시간 뇨중 $\mathrm{Zn}$ 배설량은 폐암환자 에서 $1066 \pm 592 \mu \mathrm{g} / 24 \mathrm{hr}$ 로 정상대조군의 $504 \pm 262 \mu \mathrm{g} /$ $24 \mathrm{hr}$ 에 비해 유의하게 증가하였다 $(\mathrm{p}<0.02)$.

2) 폐암의 조직학적인 유형, 진행기에 따른 혈청 및 24 시간 뇨중 $\mathrm{Zn}$ 치는 유의한 차이가 없었다.

3) 혈청 $\mathrm{Zn}$ 치가 $70 \mu \mathrm{g} / \mathrm{dl}$ 이상인 폐암환자에서 $\mathrm{OKT} 4$ 양성세포백분율, $\mathrm{OKT} 8$ 양성세포백분율, $\mathrm{OKT}_{4}^{+} /$ $\mathrm{OKT}^{+}{ }^{+}$비는 각각 $46.57 \pm 7.93 \%, 24.57 \pm 6.72 \%$, $2.00 \pm 0.59$ 였고, 혈청 $\mathrm{Zn}$ 치가 $70 \mu \mathrm{g} / \mathrm{dl}$ 이하인 폐암환자 에서는 각각 $33.0 \pm 9.79 \%, 26.57 \pm 8.94 \%, 1.39 \pm 0.54$ 로, 혈청 $\mathrm{Zn}$ 치가 $70 \mu \mathrm{g} / \mathrm{dl}$ 이상인 군에서는 정상대조군 과 거의 유사한 말초혈액 $\mathrm{T}$ 임파구아형분석의 소견을 보 였으나 혈청 $\mathrm{Zn}$ 치가 $70 \mu \mathrm{g} / \mathrm{dl}$ 이하인 군에서는 $\mathrm{OKT} 4$ 양 성세포백분율의 유의한 감소를 보였다 $(\mathrm{p}<0.02)$. 
이상의 결과로 폐암환자에서 혈청 $\mathrm{Zn}$ 치의 감소가 말 초혈액 T임파구아형에 변화를 초해할 수 있으며, 폐암 의 분화와 전이, 감염증에 대한 저항력감소등과도 관계 있을 것으로 사료된다.

\section{REFERENCES}

1) John IA, Elaine B, Maria GB, Craig JM, Allen SL, John EM: Association between urinary zinc excretion and lymphocyte dysfunction in patients with lung cancer. Am J Med 79:209, 1985

2) Morton KS: Role of trace elments in cancer. Cancer research 35:3481, 1975

3) John IA, robert TP, Craig JM, Neil EK: Alteration in human natural killer cell activity and monocyte cytotoxicity induced by zinc deficiency. J Lab Clin Med 102:577, 1983

4) Brian FI, Bruce VM, Elizabeth TG, Manuel V, Staley JD, Gerald PB: Serum zinc levels in lung cancer patients. Cancer 47:1845, 1981

5) Jean MM: Cadmium and zinc abnormalities in bronchogenic carcinoma. Cancer 25:1385, 1970

6) 이경주, 남재만, 손경선, 김주옥, 김선영 : 폐암환자의 $\mathrm{T}$ 임파구아형분석(I). 결핵 및 호흡기질환 $35: 38$, 1988

7) 서원교, 이현수, 방동수, 유지홍, 강홍모, 김원동 : 폐 암환자에서 혈청 및 노중 $\mathrm{Zinc}$ 에 관한 연구. 결핵 및 호흡기질환 34:157, 1987

8) Leon AS, Daniel TM, partrica JD, Barbara LC, Susan W, Marilyn S, David HPa: Effects of zinc deficiency on cellular processes and morphology in
Ehrlich ascites tumor cell. Cancer research 39:2457, 1979

9) Ananda SP, Donald O: Zinc deficiency in man. Lancet 30:1520, 1973

10) William BK, Allen SL, John SM, Stephen ES, Craig JM: Abnormal zinc metabolism in type II diabetes mellitus. Am J med 75:273, 1983

11) James AHJ, Fossain Ar, Parichehr A, Mansour $H$, Amirfakemi gH, Russel MB, Hohn GR: Zinc deficiency in man. Am J Med 53:277, 1972

12) John IA, Neil EK, Craig JM: Severe zinc deficiency in humans: Association with a reversible $T$. lymphocyte dysfunction. Am J Med 95:154, 1981

13) Jean D, Guy D, roger V, Henri C: Beneficial effects of oral zinc supplementation on the immune response of old people. Am J Med 70:1001, 1981

14) Garbriel F, Madhavan N, Kazunori O, Toshio T, Rachael F, Robert AG: Impariment of cell-mediated immunity functions by zinc deficiency in mice. Immunology 76:457, 1979

15) Robert SP, Harold HS, Robert AJ, Donard FB: Abnormal cellular immune responses during acquired zinc deficiency. Am J Clin Nutr 32:1446, 1979

16) Davies ITJ: Plasma-Zinc concentration in patients with bronchogenic carcinoma. Lancet January 15, 1972

17) Vassilis V, Theodore M, Vassiliki TV, Anton K, Greogory S: Serum Zinc levels and urinary zinc excretion in patients with bronchogenic carcinoma. Am J surg 144:355, 1982 